Association for Information Systems AIS Electronic Library (AISeL)

AMCIS 2003 Proceedings

Americas Conference on Information Systems

(AMCIS)

December 2003

\title{
Cultural Universality Versus Particularity in CMC
}

Bernd-Carsten Stahl

DeMontfort University

Follow this and additional works at: http://aisel.aisnet.org/amcis2003

\section{Recommended Citation}

Stahl, Bernd-Carsten, "Cultural Universality Versus Particularity in CMC" (2003). AMCIS 2003 Proceedings. 126.

http://aisel.aisnet.org/amcis2003/126

This material is brought to you by the Americas Conference on Information Systems (AMCIS) at AIS Electronic Library (AISeL). It has been accepted for inclusion in AMCIS 2003 Proceedings by an authorized administrator of AIS Electronic Library (AISeL). For more information, please contact elibrary@aisnet.org. 


\title{
CUltural Universality Versus PARTICULARITY IN CMC
}

\author{
Bernd Carsten Stahl \\ DeMontfort University \\ bstahl@dmu.ac.uk
}

\begin{abstract}
Cultural factors are often identified as a crucial influence on the success or failure of information systems in general or computer-mediated communication (CMC) in particular. Several authors have suggested ways in which management can accommodate these factors or solve the problem they pose. This paper attempts to go one step beyond management measures and ask whether there is a theoretical foundation on which one can base the mutual influence of culture and CMC. In order to find such a theoretical basis the paper discusses the question whether there are aspects of culture that are universal or whether culture is always particular. In the course of this discussion the concept of culture is defined and its relationship with technology is analysed. As a solution the paper suggests a Habermasian approach to culture which sees a universal background to particular cultures in the structure of communication which creates and sustains culture. The paper then tries to give an outlook how such a Habermasian theory of culture can enable designers and users of CMC to reflect on their activity and improve the quality and reach of $C M C$.
\end{abstract}

Keywords: Culture, computer-mediated communication, IT, Habermas, universality

\section{Introduction}

Culture is frequently named as a determinant of usability of computers. That means that the culture from which a developer, programmer, or user stems makes a difference regarding whether she is willing or able to use a certain technology. This is a robust and tenable assumption given that it is common knowledge that the success of information systems depends on many "soft" factors and the term "culture" is often used to describe some of these. However, it is also a questionable assumption when one considers that in principle all humans can interact and computers as the "malleable" technology could be customised to uses in most cultures. The problem therefore seems to be one of delineation. Up to what point do different cultures diverge and what, if anything, do they have in common? This is of interest because an answer would inform us of what analysts and designers of information systems can take for granted independent of their target culture and what parts of the systems would have to be customised or even reconceptualised.

The aim of this paper is therefore to analyse whether there is a clearly demarcated part of human culture that is universal to all cultures and, if so, what this means for computer-mediated communication. In order to be able to answer this question the paper will begin by taking a look at the meaning of the term "culture". It will be shown that culture is a rather fuzzy concept that can mean many things from shared global interpretations of meaning to specific ways of doing things within organisations. The paper will take a look at different definitions of culture and discuss the two principal views that culture is either universal or particular. In a subsequent step the relevance of this question to computer-mediated communication is discussed. It will become clear that the same question of universality versus particularity of culture can be found concerning CMC. As a solution to this problem it is suggested to take a look at the Theory of Communicative Action by Jürgen Habermas. This theory recognises the factual plurality of cultures but emphasises the fundamental underlying constant which consists of human beings and the universal structure of their communication. Finally, the implications of this approach for CMC are discussed. It will be suggested that despite pervasive cultural differences there are universals in the communication which constitutes culture. These universals can be used as starting points for the design and use of $\mathrm{CMC}$ with the purpose of facilitating cooperation. 
To some degree the topic of this paper is probably coextensive to the etic/emic debate in anthropology which is also related to the question of universal cultural concepts. However, the etic/emic debate is more interested in the question whether internal or external categories should be applied when describing cultural phenomena whereas this paper is interested in whether there are true cultural universals.

\section{Culture}

In order to determine whether the universality of culture - or lack thereof - have something to contribute to computer-mediated communication the first step should be the definition of the term. The first part of this section will therefore be dedicated to the description of several different views of what the term "culture" might in fact mean. The second part of the section will then discuss whether these definitions of culture allow us to draw a conclusion as to its universality.

\section{Definition of Culture}

For the purposes of this paper there are two dimensions of culture that are of relevance. One is the culture that a society shares, the other one is culture on a smaller level, namely organisational or corporate culture. Both of these dimensions share several aspects and refer to one another. Cultural studies usually aim at describing the macro-level of society. Here, culture can be defined as the quintessence of the physical resources and perceptions, of the physical and mental techniques which allow a society to persist (cf. Gehlen 1997, 80f). Culture thus consists of facts, artefacts, institutions etc. but its most important function is that of a reservoir of shared interpretations and collective experiences (cf. Robey \& Azevedo 1994). The process of sharing and thus constituting reality that culture implies is based on communication (Wynn, Whitley \& Myers 2003). Communication, as Castells $(2000,403)$ points out is based on the production and consumption of signs. These signs are the way in which humans understand their world and they can thus be said to constitute reality. The reliance of culture on signs as a means to interact is a fact that can be observed on the societal (Galtung 1998) as well as the organisational level (Ward \& Peppard 1996).

For the question of the influence of culture on CMC the aspect that seems most important is the sharing of interpretations. Communication as the basis of culture is only possible given the assumption that the participants share some experiences, some knowledge in order to be able to communicate at all. To a certain degree a shared culture is thus necessary to communicate but it is also the result of communication. Culture is the basis and the result of a self-referential process. This process defines what is perceived as natural and normal, it defines the way things are (Galtung 1998b). In this sense culture is enormously powerful because it shapes reality. It contains not only the facts of a society but also its aspirations, its shared utopia (Bourdil 1996). That means that it has a strong normative aspects because it contains and justifies the accepted morality and the permissible ethical theories. "The concept of culture is a value-concept" (Weber 1994, 71).

This normative side of culture can also produce problems. The agreed-upon utopia of a society may be a bad one in the sense that it endorses values that are objectionable from the point of view of other cultures, such as racism or totalitarianism (French 1992). Furthermore, if the power of definition in a culture becomes rigid and encrusted then it can also turn into an ideology, a fact that is emphasised by cultural criticism and ideology critique (Schultze \& Leidner 2002).

There are several other aspects of culture that are worth mentioning. One of them is that culture is closely linked with technology and has even been reduced to technology (Meihorst 1998). The history of culture is always also the history of technology. It is part of the human condition to be able to change and form nature according to our needs. Culture is the frame of this technologybased use of nature (Höffe 1995). One can therefore say that culture is one of the constants of human beings and that the nature of humans determine their culture.

Another aspect of culture that is important in the context of using computers to communicate is the culture of an organisation. As already noted this type of culture is closely linked to the meta-level of societal culture but also slightly different from it. Corporate culture can be defined as "commonly shared values which direct the actions of the employees towards the common purpose of the enterprise [...]. Corporate culture understood as the totality of existing and practised values, forms the moral basis of all corporate activities" (Steinmann 2001, 11). Corporate or organisational culture fulfils the same role in an organisation that culture fulfils in society. It defines what is real, what is important, and thus how one should act. This has led to an extensive use of the term as a vehicle of business ethics (Meyer-Dohm 1994; Grabner-Kräuter 2001). 
This importance of organisational culture has at the same time led to some problems and misunderstandings. If culture is central to an organisation's perception of and interaction with the world then it is clearly in the interest of management to control and manage it (Ward \& Peppard 1996; Robey \& Azvedo 1994). However, if culture is the basis of the understanding of the world then it is questionable in how far such an instrumental use is possible. Furthermore, given the ethical nature of culture it is also doubtful whether management of culture is desirable or morally admissible. Also, there remains the open question of the guidelines according to which organisational culture is to be managed and maybe improved (Ulrich 1997).

All of these questions have an impact on how technology can be used. They show that culture is an important variable in CMC. So far it remains open, however, whether culture is really a useful variable in this context or whether it is an umbrella term used to collect aspects that are otherwise incommensurable. An important part of the answer to this question depends on whether there is something that all cultures share, which would mean that culture is partially universal, or whether different cultures are fundamentally different and particular.

\section{Universality Versus Particularity of Culture}

There are undeniably different cultures on a societal as well as an organisational level. Given this fact one can ask the question how deep the differences run. In this paper we will distinguish between two possible answers to this question. The proponents of particularity of culture on the one side believe that different cultures are fundamentally and possibly irreconcilably different, whereas the proponents of universality believe that all cultures share some universal attributes. These two ideal-typical positions appear in reality in different shades of grey. For the purposes of this discussion we will attempt to portray them as unequivocal as possible.

The particularist interpretation of culture says that different cultures differ in all possible ways and that there is nothing that binds them together. This means that the sense-making function of culture is limited to the members of a certain culture and sense and meaning may not be translatable from one culture to another. If this is correct then the meeting of different cultures will lead to misunderstandings and frequently to conflicts. On a global scale this scenario has been proposed by Samuel Huntington's thesis of the "clash of civilisations" (Huntington 1993). Another indicator that could be taken to mean that cultures are irreconcilably particular is that of morality (French 1992). We have seen that moral norms are an integral part of cultures and a look at existing moralities shows that they are often diametrically opposed. Some cultures believe in the sanctity of life, others in capital punishment. Some believe in forgiveness, others in retaliation. There are head-hunter and cannibal cultures as well as cultures that promote peace and forgiveness.

The universalists on the other hand concede that there are factual differences between cultures but contend that these are limited and that there are underlying commonalities. The possibly most important argument for this viewpoint is that despite the differences in cultures there has always been exchange of goods and ideas between different cultures. If this is possible, they would argue, then it means that people can share meaning and their life-worlds, albeit in an imperfect way. However, it means that translation of language and meaning is possible which in turn indicates that culture as the carrier of language and meaning should have universal aspects. This argument is strengthened by the social development that is often called "globalisation". Several authors emphasise that globalisation means that different cultures become more similar, or may even merge to a certain degree (Koslowski 1997; Beck 1998). The international and trans-cultural use of ICT that is the centre of this paper is just one example for this.

If one agrees with this univeralist view the next question is: what is it that is universal to all cultures? One possible answer that will be the basis of the further argument of this paper is that what all cultures have in common is their nature as social constructs and the fact that they originate from human beings. The commonalities of all cultures are thus based on the commonalities of all humans. Universalism of culture is a result of anthropological constants. Among these anthropological constants we can find the fact that humans live a self-formed and technical environment (Lenoir, R. 1997; Gehlen 1997). The very fact that humans create culture in order to survive is one of the constants of humanity that form a universal basis of culture (cf. Weber 1994). Not only do humans collectively build cultures but they also require a cultural background to develop an individual and collective identity (Castells 2000; Dehner 1998). Also, there are several existential similarities between all humans that affect our cultures. Among them there are our bodily and fragile existence and the fact that we face death and know about it (Lübbe 1990).

The conclusion in this paper is that, despite obvious difference in cultures, there are similarities that are based on human nature. Before we can proceed to the question how these cultural commonalities can be used for the purposes of computer-mediated communication we will use the next section to analyse the state of the discussion concerning the influence of culture on CMC. 


\section{Culture and CMC}

Having introduced the discussion regarding particularity versus universality of culture in general terms this section will be dedicated to the influence of culture on CMC. In the first step it will look at the relationship of culture and IT in order to then proceed to the influence of culture on $\mathrm{CMC}$ in a narrower sense. The chapter will end by reviewing the arguments for and against universality of culture in CMC.

\section{Culture and IT}

Information technology is always incorporated into social practices without which it would be useless. Information systems as the study of IT in organisations, for example, tends to explicitly recognise social and cultural processes as part of its research object (Lyytinen / Hirschheim 1988). There is a mutual influence of IT and culture and we will first look at the influence of IT on culture and then turn our view to see what influence culture has on IT.

Many texts concerning the impact of IT on culture tend to concentrate on corporate culture and here on the relationship between IT and organisational change. Organisational change affects organisational culture and, in order to be successful, must be supported by a culture that allows change. IT is frequently seen as a driver and facilitator of change. However, there is no clear relationship between change and IT. IT has a certain "interpretive flexibility" which allows it to be used by most parties and for most purposes.

"Interpretive flexibility allows users to reinvent technology to serve interests beyond its intended purposes, and new cultural practices may be forged as actors quietly depart from accepted practices in order to rectify structural contradictions." (Robey \& Azevedo 1994, 32)

The change in the organisation that IT may bring about can lead to more flexibility, for example in working hours (Himanen 2001), but also to less flexibility, for example through electronic surveillance. While this argument concerning the relationship of IT and change tends to be made on an organisational level it is also applicable to the societal level. On the one hand the information society that we supposedly move towards can be seen as a harbinger of change in all areas of life, whereas on the other hand, one can argue that information technology is a necessity for keeping social structures stable in the face of environmental change (Weizenbaum 1976). Another aspect of culture that may be subject to change due to the use of IT are values and norms, which can have immense political and moral impetus (Chapman \& Rotenberg 1995).

IT can thus lead to change that will affect culture but at the same time the prevailing culture can also affect IT. Culture in the sense of a meaning-constituting horizon of the collective life-world determines the perception and use of IT. This is again true for the organisational level where culture can influence whether employees are able and willing to use certain technologies. It is also true on a societal level where culturally based perceptions have some bearing on the use of IT. A national culture that emphasises sharing and the collective, for example, will lead to different uses of IT than one that emphasises the individual and competition (Raboy 1997; Riis 1997).

\section{Culture and CMC}

Before the background of the mutual influence of culture and IT we can now proceed to look at the relationship of culture and computer-mediated communication. It is important to keep in mind our central research question, namely the problem of cultural particularity versus universality, which is supposed to help us eventually determine how the cultural aspect can be taken into account in the design and use of IT used for communication.

Computer-mediated communication here stands for the use of information and communication technology for the purpose of exchanging information. This is a wide definition that includes many applications such as fax or mobile telephones that are not necessarily part of CMC. However, it seems to be useful to choose a wide definition in order to keep an open mind regarding possible new developments. Nevertheless, there are two technologies that are the typical representatives of CMC: the Internet and email. These are widely used today and they are also researched quite extensively (Agarwal / Rodhain 2002). The characteristics of CMC are often such that they situate it between or beside traditional forms of communication. Email communication, for example, is neither exactly like spoken language but it is not directly comparable to written language either (Kolko 2000; O'Leary \& Brasher 1996). 
There is a multitude of different interactions between culture and CMC. These interactions are not linear or predictable. Different applications of $\mathrm{CMC}$ "change the way people interact; they generate whole new functioning institutions. Like the market or democracy, these innovations have a life - a social evolutionary dynamic - of their own" (Danielson 1996, 70). However, it is not always clear how and in which direction these changes develop. The reason for this is that $\mathrm{CMC}$ reflects the culture in which it is used (Castells 2000). The same technology can thus be used for different ends in different contexts.

CMC also influences other parts of culture in different ways. One of the cultural area where ICT has a huge influence is that of ethics. We have seen before that ethics and moral norms are an integral part of all cultures. These norms are affected in different ways by the use of computers. Examples of this could be the changing quality of communication. CMC tends to concentrate on written communication and neglect the non-verbal part, which, according to some observers, carries the majority of meaning. Another problem might be the invisibility of the other as a human being behind technology. Some ethical theories emphasise the other and our recognition of the other as someone similar but different from ourselves as a central part of ethics (Ricoeur 1990; Levinas 1983; van den Hoeven 2000). Other moral aspects of CMC could be the effect it has on our perception of gender (Herring 1996), privacy (Kolb 1996) or a host of other moral problem.

\section{Universality of Culture and CMC}

Having argued that there is a close link between CMC and culture the next step in this argument is to check whether the influence of culture on CMC is universal or particular. Not surprisingly, the same arguments about universality versus particularity of culture that were outline above can be found here again. On the one hand there is the universality argument which is supported by the fact that ICT has a world-wide reach and appears to be used in similar ways independent of the prevailing culture. The prime example here is clearly the Internet which not only seems to be culture independent but may even produce a new universal world-wide culture (Lévy 1997).

On the other hand one can find the argument that this apparent universality of technology and its accompanying culture is just a deception and that the cultural differences run deeper. It has been argued that the homogeneity of technology use is not based on cultural universals but instead on cultural imperialism. This sort of argument contends that the uniformity of technology is not natural but the result of the application of power with the aim of creating big markets (Weckert 2000). Another example is that of e-government and e-democracy which is among the high promises of CMC but which does not progress uniformly in different cultures (Ess 2002). Similar observations have also been made on an organisational level. The cultural context determines the usability of CMC, for example by favouring certain types of communication over others. Ess (2002b) mentions that the ratio of content to context in communication or the status of anonymity which differ between cultures and affect CMC.

\section{Habermasian Culture and CMC}

In this section I will give a brief description of a theory of culture from the point of view of Habermas theory of communicative action. In a second step I will then analyse what this can mean for CMC and whether it can help the design and use of ICT.

\section{A Habermasian View of Culture}

So far we have established that culture and CMC are intertwined in a complex relationship and that both sides of the universal versus particular debate have good arguments. In order to overcome the apparent contradiction between the two positions I suggest a Habermasian view of culture that would allow the simultaneous admission of cultural pluralism and universalism. Briefly, this theory is based on Habermas (1981) theory of communicative action which holds that our reality is shaped by discourses. These discourses consist of arguments concerning contentious validity claims. Every speech act contains at least three validity claims, namely truth, legitimacy, and authenticity. Whenever the claims of a speech act are doubted the affected parties are called upon to clarify them in a discourse. Discourses are acts of communication that are characterised by the fact that they emulate the ideal discourse in which there would be no distortions due to power differences, different abilities etc. and where only the better argument would count. The result of such discourses would be a consensus about the validity claims which would then constitute part of the life-word.

In terms of this paper that means that discourses constitute culture, that they are the resource that produces the collective knowledge, values and perceptions that we defined as culture. In Habermas theory there is a close relationship between culture, 
society, and person (Habermas 1998). In this framework it is not problematic to concede that there are different cultures that affect our use of technology. Different people have different life-worlds and different cultures can develop according to different perceptions. However, there are universals combining these particularities and that constitute cultural universals. The first universal is that all humans have a culture and that culture is a constitutive part of personality. Second, the way a culture is formed by discourse is universal. While discourses deal with different matters, their structures and the fact that they are built upon validity claims is universal.

\section{The Impact of Habermas' Theory of Culture on CMC}

A Habermasian view of culture can support the use and development of CMC in different ways. On the one hand there are theoretical considerations as discussed above. It helps overcome the apparent dichotomy of universality versus particularity of culture by offering a way of seeing the universal in the particular. By opening this view, the Habermasian understanding of culture firstly sharpens the attention to culture and secondly points towards ways of incorporating cultural factors in CMC. Different cultures can be understood as different voices in a discourse and different cultural perceptions can be interpreted as validity claims. The intercultural differences about validity claims can then be taken as a starting point of discourses. While this is quite abstract and would lead to considerable difficulties when realised, it is a way of, for example, identifying risk factors that particular cultures might overlook. An inter-cultural approach has therefore been identified as one way of risk management in software engineering (Schmidt et al. 2001).

At the same time, the Habermasian understanding of how discourses shape culture and thus reality can help us design technology used for communication. First, one should realise that culture is a necessary background for all understanding and all technology and that it cannot be used in a strategic manner. Management may try to shape organisational culture but this is only possible in a very limited way. It is impossible to predict the exact way in which culture and CMC will interact.

However, the structure of communication and validity claims outlines principles that are valid for CMC just as for every other type of communication. While the actual validity claims that interlocutors can make in the course of communication or a discourse are not predictable, the type and relevance of these claims is known. Independent of who says what about which subject, there will be claims of truth, legitimacy, and authenticity involved. Furthermore, in order to gain acceptability it must be possible to question these claims and exchange arguments about them. This is the area where CMC designers can take quite direct cues from Habermas' theory.

An important one of these cues is that the validity claims that constitute communication are always connected. That means that the distinction of truth, legitimacy, and authenticity is useful for analytical purposes but real communication contains all of them simultaneously. Every speech act contains them either explicitly or implicitly and the validity of one claim cannot be completely distinguished from the others. This is relevant because it underlines that the attempt to use IT as a means of transmitting "objective" truth claims in the form of data is doomed to failure when it neglects that truth always must be legitimate and reflect on the speaker. This is what many IS researcher who use the Foucault's theoretical framework point out when they speak about power and knowledge, about regimes of truth. Unlike the Foucauldians, for whom truth remains particular, the Habermasian approach allows the identification, if not of truth, then of the legitimate way of determining truth.

While this is something most users of technology may be aware of, the bigger problem tends to be how to find a solution. Our Habermasian approach has so far informed us that beneath all of the cultural particularities and peculiarities there exists a universal structure of communication. The question that needs to be answered is, how should we deal with differences and how can these insights help us improve the design and use of technology for communication? The answer lies in Habermas' central construct of discourse. While validity claims and their cultural expressions differ, these differences can be addressed by establishing discourses. In Habermas' theories discourses appear in at least two places. On the one hand there are real discourses in which affected groups and people discuss factual validity claims. On the other hand there is the ideal discourse in the ideal discourse community which functions as the ideal that real discourses need to emulate in order to come to acceptable conclusions. Both of these functions, real and ideal discourses can help us in CMC.

First, there are real discourses. In order to overcome cultural particularity CMC should allow the users first of all to express their validity claims clearly. These validity claims, in order to gain interpersonal validity, must be questioned. If CMC carries validity claims, then this means that it must allow for the critical discussion of these claims. This is a central problem of many information system because they incorporate and are based on particular assumptions that are on the one hand hard to identify and on the other hand even harder to change. In order to allow intercultural communication and facilitate general use, CMC must therefore be of 
a flexible nature and allow for unforeseen criticism. A second conclusion to be drawn from real discourses is that it is important to allow those parties that are affected to have a voice in the discussion of disputed claims. This stakeholder approach has an ethical background(Donaldson \& Preston 1995) but has also been shown to be useful for straightforward questions of systems design and project definition as described by Metcalfe \& Lynch (2003).

Second, the idea of the ideal discourse and the ideal discourse community can serve as guidance in the design and use of IT. If stakeholder discourses are to be facilitated then it is important to do so in such a way that the results are acceptable. This means that the distortions that are always part of real communication are realised and minimised. CMC should emulate the possibilities of communication that are given in real communication. There are interesting approaches that try to visualise frequency of CMC use, for example, which will give participants an idea of the status of speakers (Erickson et al. 2002). Technology can be used to make its own use more transparent (Smith 2002), which in turn is part of the Habermasian ideal discourse. These are just some examples of how technology can be used to move CMC closer to ideal conditions of discourse which can be seen as universal and culture-independent.

\section{Conclusion}

In this paper I have tried to show that culture is of high importance for the design and use of ICT and CMC. This importance of culture finds its relevance in the fact that the successful use of CMC depends in large parts on the underlying societal and organisational culture. Given the obvious difference between cultures the paper has tried to find out whether there are cultural universals that allow the determination of general principles of design and use. Using a Habermasian framework I argued that there are cultural universals that are based on the anthropological constant of communication and the universality of validity claims. I have tried to show that from such a Habermasian framework one can draw conclusions concerning the actual use of ICT. The paper is conceptual and tried to show that Habermas' work is relevant in CMC. It was not the purpose of the paper to develop practical applications or demonstrate examples. The conceptual approach distinguishes it from other research in culture and ICT / business such as Hofstede's or Trompenaar's. Empirical research on the basis of this paper should be possible but it would constitute the next step.

As a final remark I want to point to the limits of this approach. Using a Habermasian concept of culture can be used to draw conclusions regarding the use of ICT. However, one should keep in mind that in a way this inverts the relationship of culture and ICT. Technology is always embedded in a greater cultural setting and it is meant to serve communication that is used to create and maintain this culture. This precludes us from an instrumental use of culture and shows that technology is just one possible solution to some problems that arise in society. The question of cultural universality versus particularity is one that has an impact on CMC but it goes far beyond it. Questions of cultural universality have political, social, and ethical implications and the use of technology in this context carries the danger of turning into cultural imperialism. Furthermore, the use of a theory of culture to facilitate CMC carries the threat of turning into a self-fulfilling prophecy (Johnson 2001).

In order to understand culture, to understand and accept cultural differences, and to overcome them where necessary, CMC can only be a minor tool. What is more important is an awareness of the problem and a willingness to accept cultural differences. One important approach to this will be education (Ess 2002b; O'Leary \& Brasher 1996). The topic of this paper should thus be understood as a minor excerpt of the greater question of how we should deal with different cultures. The question of CMC and culture should thus be seen in context and understood as an important but dependent aspect of a greater discourse.

\section{References}

Agarwal, R. \& Rodhain, F. "Mine or Ours: Email Privacy Expectations, Employee Attitudes, and Perceived Work Environment Characteristics," Proceedings of the 35th Annual Hawaii International Conference on Systems Sciences, Hawaii, January 7-10, 2002.

Beck, U. Was ist Globalisierung? Irrtümer des Globalismus - Antworten auf Globalisierung. 5th edition, Frankfurt a. M.: Edition Zweite Moderne, Suhrkamp Verlag, 1998.

Bourdil, P-Y. (1996): Le temps. Paris: ellipses / édition marketing.

Castells, M. The Information Age: Economy, Society, and Culture. Volume I: The Rise of the Network Society. $2^{\text {nd }}$ edition Oxford: Blackwell, 2000.

Chapman, G. \& Rotenberg, M. "The National Information Infrastructure: A Public Interest Opportunity, “ Johnson, D. G. \& Nissenbaum, H. (eds.), Computers, Ethics \& Social Values. Upper Saddle River: Prentice Hall, 1995, pp. 628 - 644. 
Danielson, P. "Pseudonyms, MailBots, and Virtual Letterheads: The Evolution of Computer-Mediated Ethics," Ess, C. (ed.) Philosophical Perspectives on Computer-Mediated Communication. Albany: State University of New York Press, 1996, pp. $67-93$.

Dehner, K. Lust an Moral. Die natürliche Sehnsucht nach Werten. Darmstadt: Primus Verlag, 1998.

Donaldson, T, \& Preston, L E, “The Stakeholder Theory of the Corporation: Concepts, Evidence, and Implications," in: Academy of Management Review 1995, Vol 20, No 1, pp. 65 - 91.

Erickson, T et al., "Social Translucence - Designing Social Infrastructures that Make Collective Action Visible," in: Communications of the ACM (45:4), 2002, pp. 40 - 44.

Ess, C "Computer-mediated Colonization, the Renaissance, and Educational Imperatives for an Intercultural Global Village," Ethics and Information Technology (4:1), 2002, pp. 11 - 22.

Ess, C “Cultures in Collision: Philosophical Lessons from Computer-Mediated Communication” Metaphilosophy(33:1/2), Special Issue: Cyberphilosophy: The Intersection of Philosophy and Computing. Edited by J.H. Moor and T.W. Bynum, 2002b, pp. $229-253$.

French, P A. Responsibility Matters. Lawrence, Kansas: University Press of Kansas, 1992.

Galtung, J Die andere Globalisierung: Perspektiven für eine zivilisierte Weltgesellschaft im 21. Jahrhundert. Münster: agenda Verlag, 1998.

Galtung, J Frieden mit friedlichen Mitteln - Friede und Konflikt, Entwicklung und Kultur. Opladen: Leske + Budrich, $1998 \mathrm{~b}$.

Gehlen, A Der Mensch: seine Natur und seine Stellung in der Welt. 13th edition Wiesbaden: UTB, 1997.

Habermas, J. Faktizität und Geltung: Beiträge zur Diskurstheorie des Rechts und des demokratischen Rechtsstaats. Frankfurt a. M.: Suhrkamp, 1998.

Habermas, J Theorie des kommunikativen Handelns, Frankfurt a. M., Suhrkamp, 1981.

Herring, S "Posting in a Different Voice: Gender and Ethics in Computer-Mediated Communication, " In: Ess, C (ed.) Philosophical Perspectives on Computer-Mediated Communication. Albany: State University of New York Press, 1996, pp. $115-145$.

Himanen, P. The Hacker Ethic and the Spirit of the Information Age. London: Secker \& Warburg, 2001.

Höffe, O. ral als Preis der Moderne: ein Versuch über Wissenschaft, Technik und Umwelt. 3rd edition Frankfurt a. M.: Suhrkamp, 1995.

Huntington, S.P. The Clash of Civilisations? In: Foreign Affairs Summer 1993 Volume 72, Number 3, pp. 2 - 49.

Johnson, D. G. "Ethics On-Line," in: Spinello, R A. \& Tavani, H T. (eds.) Readings in Cyberethics. Sudbury, Massachusetts et al.: Jones and Bartlett, 2001, pp. 26 - 35.

Kolb, D “Discourse Across Links," In: Ess, Charles (ed.) Philosophical Perspectives on Computer-Mediated Communication. Albany: State University of New York Press, 1996, pp. 15 - 26.

Kolko, B. E. "Intellectual Property in Synchronous and Collaborative Virtual Space, “: Baird, R. M., Ramsower, R. \& Rosenbaum, S E. (eds.) Cyberethics - Social and Moral Issues in the Computer Age. New York: Prometheus Books, 2000, $257-281$.

Koslowski, P. Weltwirtschaftsethos (Global Economic Ethos): Globalisierung und Wirtschaftsethik. Wien: Passagen Verlag, 1997.

Lenoir, R.: “Entretien avec René Lenoir,” Lenoir, F. (ed.) Le temps de la responsabilité - Entretiens sur l'éthique. Paris: Fayard, 1997, pp. 97 - 118.

Levinas, E, Le temps et l'autre. Paris: Quadrige / Presses Universitaires de France, 1983.

Lévy, P Cyberculture. Paris: Editions Odile Jacob, 1997.

Lübbe, H Der Lebenssinn der Industriegesellschaft - über die moralische Verfassung der wissenschaftlich-technischen Zivilisation. Berlin et al: Springer Verlag, 1990.

Lyytinen, K / Hirschheim, R. (1988): "Information Systems as Rational Discourse: an Application of Habermas Theory of Communicative Action," Scandinavian Journal of Management (4:1/2), 1988, pp. 19 - 30.

Meihorst, W. "Zukunftsorientierung des Ingenieurberufs und Ingenieureid," Zimmerli, Walther Ch. (ed.) Ethik in der Praxis Wege zur Realisierung einer Technikethik (Mensch - Natur - Technik; Bd. 6). Hannover: Lutherisches Verlagshaus, 1998.

Metcalfe, M \& Lynch, M, “Arguing for Information Systems Project Definition,” in: Wynn, E; Whitley, E; Myers, M D. \& DeGross, J (eds.) Global and Organizational Discourse About Information Technology: Ifip Tc8/Wg8.2 Working Conference on Global and Organizational Discourse About Information Technology, December 12-14, 2002, Barcelona, Spain. Dordrecht: Kluwer Academic Publishers, 2003, pp. 295 - 321.

Meyer-Dohm, P. "Lernkultur im Unternehmen: Bildungsarbeit als Voraussetzung von Technikverantwortung," In: Zimmerli, W. Ch., \& Brennecke, V. M. (eds) Technikverantwortung in der Unternehmenskultur - Von theoretischen Konzepten zur praktischen Umsetzung. Stuttgart: Schäffer-Poeschel Verlag, 1994, pp. 73ff. 
O'Leary, S D. \& Brasher, B. E. "The Unknown God of the Internet: Religious Communication from the Ancient Agora to the Virtual Forum," Ess, C. (ed.) Philosophical Perspectives on Computer-Mediated Communication. Albany: State University of New York Press, 1996, pp.: 233 - 269.

Raboy, M. (1997): "Cultural Sovereignty, Public Participation, and Democratization of the Public Sphere: The Canadian Debate on the New Information Infrastructure," Kahin, B \& Wilson, E J. (eds.) National Information Infrastructure Initiatives Vision and Policy Design. Cambridge, Massachusetts, and London, England: MIT Press, 1997, pp. 190 - 216.

Ricoeur, P. Soi-même comme un autre. Paris: Edition du Seuil, 1990.

Riis, A M "The Information Welfare Society: An Assessment of Danish Governmental Initiatives Preparing for the Information Age," Kahin, B \& Wilson, E J. (eds.) (1997): National Information Infrastructure Initiatives Vision and Policy Design. Cambridge, Massachusetts, and London, England: MIT Press, 1997, pp. 424 - 456.

Robey, D. \& Azevedo, A. "Cultural Analysis of the Organizational Consequences of Information Technology," Accounting, Management and Information Technologies (4) 1, 1994, pp. 23 - 37.

Schmidt, R et al. "Identifying Software Project Risks: An International Delphi Study," in: Journal of Management Information Systems (17:4), 2000, pp.. 5 - 36.

Schultze, U \& Leidner, D "Studying Knowledge Management in Information Systems Research: Discourses and Theoretical Assumptions," MIS Quarterly (26:3), 2002, pp. 213 - 242.

Smith, M. "Tools for Navigating Large Social Cyberspaces, " in Communications of the ACM (45:4), 2002, pp. 51 - 55.

Steinmann, H. "Business Ethics in a Modern Society," Business Ethics in a Modern Society (Estonian Business School Review No 12). Talinn: EBS, 2001, pp. 11 - 18.

Ulrich, P Integrative Wirtschaftsethik - Grundlagen einer lebensdienlichen Ökonomie. Bern, Stuttgart, Wien: Haupt, 1997.

van den Hoeven, J, "The Internet and Varieties of Moral Wrongdoing," Langford, D (ed.), Internet Ethics, London: McMillan, 2000, pp. $127-153$.

Ward, J \& Peppard, J "Reconciling the IT/business relationship: a troubled marriage in need of guidance," Journal of Strategic Information Systems 5, 1996, pp. 37 - 65.

Weber, M "Objectivity and understanding in economics," Hausman, D M. (ed.) The Philosophy of Economics: An Anthology. $2^{\text {nd }}$ edition Cambridge: Cambridge University Press, 1994, pp. 69 - 82.

Weckert, J “What is New or Unique about Internet Activities?” In: Langford, D (ed.): Internet Ethics. London: McMillan, 2000, pp. 47 - 63.

Wynn, E H., Whitley, E. \& Myers, M. "Placing Language in the Foreground: Themes and Methods in Information Technology Discourse," Wynn, E; Whitley, E; Myers, M D. \& DeGross, J (eds.) Global and Organizational Discourse About Information Technology: Ifip Tc8/Wg8.2 Working Conference on Global and Organizational Discourse About Information Technology, December 12-14, 2002, Barcelona, Spain. Dordrecht: Kluwer Academic Publishers, 2003, pp. 1 - 12. 